\title{
A Proposed Mathematical Model to Improve Workforce Scheduling at Maintenance Department of Rabigh Independent Power Plant
}

\author{
Ali M. Jaafari and Reda M. S. Abdulaal \\ Industrial Engineering Department, Faculty of Engineering, King Abdulaziz University, Jeddah, \\ Saudi Arabia \\ amj.655@gmail.com
}

\begin{abstract}
In power producing industries, the maintenance is a crucial part to keep the availability and reliability of plant's system at optimum level. The optimum utilization of maintenance resources such as workforce, material and equipment are a key process to achieve organization's profit goals. This paper studies the maintenance workforce scheduling at Rabigh Independent Power Plant in Saudi Arabia. It is aimed at determining optimum workforce schedules to limit the increasing demand for overtime during 5 working days of the week and 2 days of weekend and ultimately reducing the cost of workers' overtime by utilizing the available worktime within minimum requirements. A mathematical programming model is proposed for scheduling workforce with a scenario of two consecutive days off per week. This model is applied for mechanical maintenance workforce with $25 \%$ and $67 \%$ reductions of the yearly pay hours cost and overtime cost, respectively, compared with the existing scheduling workforce scenario.

Keywords: Workforce scheduling, Cost analysis, Power plant's reliability, Mathematical programming, Maintenance working policies.
\end{abstract}

\section{Introduction}

The investment in power generation is very good business where the revenue is very huge as it reached globally in 2015 to 1.8 trillion US\$ ${ }^{[1]}$ and for the Gulf Cooperation Council (GCC) in 2016 to 51 billion US\$ ${ }^{[2]}$. On the other hand, it is very costly when there are losses in power production. The Kingdom of Saudi Arabia is experiencing rapid growth in electricity demand; hence, it is forecasted for eleven years 2011-2021 to grow up to more than $60 \%{ }^{[3]}$. This rapid growth creates diverse range in power investment competitions. Power plants' operation and maintenance organizations must survive the competition and reduce maintenance cost more efficiently.
In the electricity generating plants, the maintenance is a crucial part to keep the availability and reliability of plant's system at optimum level. A Power Plant organization requires operation for 7 days / 24 hours. Therefore, the question arising to maintenance and operation's investors is how to keep the plant available all the time to avoid power production losses. The answer is to assign sufficient and competent maintenance team (i.e., optimize maintenance team schedule). Many industries have become service oriented and cost conscious, so the quality of service has become a challenge to survive in the market's competition to provide excellent service with minimum resources and cost. The optimum utilization of maintenance resources 
such as workforce, material and equipment is a key process to achieve required quality of service.

The paper is organized as follows. In the following section 2 some of literature review is presented on personnel scheduling solution techniques. The workforce scheduling problem under investigation is described in section 3 . In section 4, the solution methodology is proposed. Section 5 is validated this methodology using a real case study with numerical data. Finally, section 6 provided some conclusions on the results obtained and recommendations for future work.

\section{Litrature Review}

The variety and types of work schedules, that need to be prepared periodically complicated by workforce needs, availability, fluctuations in demand, and organizational objectives. Human resource managers in organizations were looking for solutions to control their staff and operations over a planned time horizon. Therefore, there were many studies in workforce scheduling, found in the literature, with different techniques and developments according to work constraints and assumptions [4, 5]. Popular solution techniques were towards using mathematical models such as linear programming, integer programming, mixed integer linear programming, dynamic programming, goal programming, and other methods.

Alfares et al. [6], optimized the maintenance workforce scheduling at Afam power station in Nigeria to solve the problem of increasing plant maintenance load which requires workers to be assigned to the weekend work on overtime basis. Three alternatives were compared; five-day workweek (alternative I), switch to seven-day workweek for morning shift only (alternative II), and seven-day workweek schedule for all three work shifts (alternative III) to determine the optimum schedule to satisfy growing maintenance labor requirements with minimum cost and highest efficiency. The (5, 7) work schedule was presented as an integer linear programming model. The optimum solution for alternative I is that workforce size requirement was 30 workers and weekly pay hours was 1762. The optimum solution for alternative II is that workforce size requirement was 33 and three shifts pay hours per week was 1702, whereas alternative III workforce size was 37 and pay hours per week is 1570. Ikuobase, et al. ${ }^{[7]}$, developed a software for $(5,7)$ problem given by Alfares, et al. ${ }^{[6]}$, to produce a seven days schedule for Afam power station in Nigeria.

The software was capable of determining workforce size and assigning workers to daysoff pattern operating a 7 day a week. When the software was tested with real data from Afam power station, the results showed saving of $11 \%$ maintenance labor cost annually. Jonas, et al. ${ }^{[8]}$, presented a Mixed Integer Programming (MIP) that allows defining the optimal number of employees combining flexible shift scheduling with a task scheduling problem to cope with steadily increasing healthcare costs of new type of employees who take over logistic tasks from nurse. A column generation-based solution approach was presented and found optimal solutions. Neither the general model nor the solution approach was limited to logistics assistants but can also be applied to other problem settings in the healthcare industry and beyond. The approach was tested with 48 problem instances in total and compared to benchmarks. As part of the solution approach, a lower bound for staff minimization problems with an unknown number of available workers were presented. The results showed that flexibility in shift scheduling and task scheduling leads to a decrease of $40-49 \%$ of the required workforce, compared to the non-flexible case. Mohsen et 
al. ${ }^{[9]}$, proposed a stochastic optimization model for heart surgery department in Razavi hospital, in Iran, to address the uncertainties of information about management objectives and nurse preferences and generate qualified and optimal schedules to minimize the regular and overtime assignment costs. They conducted two algorithms to solve Nurse Scheduling Problem (NSP) model. The first one was the Expected Value Problem (EVP), with deterministic situation, that yielded unsatisfactory results. The second one was Sample Average Approximation (SAA) algorithm that used to solve the Stochastic Nurse Scheduling Problem (SNSP).

A simulation study was conducted to show the advantages of SNSP algorithm over EVP model. Adel [10], developed a mathematical model to find out the optimal size of maintenance workforce with different skill levels and from different work sources needed to meet the forecasted maintenance workload and the healthy work backlog that were required to be performed in a specific planning horizon. The model dealt with minimizing the maintenance workers cost as well as the backlog of maintenance work cost. The cost of backlogging maintenance works was different from maintenance grade to another and from month to month, then the model picked this change in the data and gave results that were congruent with the change that has been made. Moustafa and Hesham [11], presented a Dynamic Programming (DP) algorithm for solving a labor scheduling problem with several realistic days off scheduling constraints and a cost structure that depends on the work sequence for each employee to minimize the total labor cost. The schedule of workforce was subjected to some assumptions such as, each employee works no more than 3 days per week, at least 2 consecutives off days per week, no more than 4 consecutive workdays per work stretch, and the number of employees working at any day $\mathrm{t}$ is equal to $r(t)$. where $r(t)$ is the number of employees needed in the $t^{\text {th }}$ day. The DP algorithm was applied to the real-life problem of night shift assignment for security personnel in a university campus with minimum number of workers.

\section{Personnel Scgeduling Problem at Ripp's Maintenance Department}

Rabigh Independent Power Plant (RIPP) is specialized in operating and maintaining electrical power. The plant contains a lot of systems and subsystems with different types of machines and processes running 24 hours to produce electricity. There are critical systems in the plant, which are mandatory to keep the production continuous. Any failure to these systems will cause loss in production either partially or completely. For example, one-day complete loss of one production unit will cost around 1.3 million Saudi Riyal. Based on this illustration, a lot of planned and unplanned maintenance must be processed daily. The maintenance management team complain that the current mechanical maintenance workforce is not sufficient to handle daily activity to complete them in the same day or even in the planned duration and hence there is need for more time along with the official working days. The demands for maintenance extended to cover even during the weekends. The management has concern about excessive overtime that is being taken in daily basis and in the weekend. The official working days are from Sunday to Thursday 5-days a week. Although workforce is not sufficient as declared by maintenance team, the management tries to optimize the number of employees since they believe that there is problem in resource planning and scheduling. Two main objectives required to achieve which are: (1) Specifying optimum workforce schedules, at RIPP, to limit the increasing demand for overtime during the 5 working 
days of the week and 2 days of weekend and (2) Reducing the cost of labors' overtime by utilizing the available worktime within minimum requirements.

\section{The Proposed Solution Methodology}

The proposed methodology to solve the problem facing RIPP's maintenance department consists of two main phases. Phase I focuses on data collection and analysis for mechanical maintenance personnel only, while Phase II handles the proposed model formulation.

\subsection{Phase I: Data Collection and Analysis}

The following data were considered as variables: the daily requirement of mechanical maintenance workforce, the number of available workforces and the average overtime wage for one hour, the premium pay hours per week, and the total overtime cost for one year. To analyze the data and generate the daily workforce requirement, the analysis is organized in four steps.

\section{Step 1: Workforce requirement analysis from one-year overtime record}

The current mechanical employees of maintenance department at RIPP are 15 workers. Based on 30 working days per month and 8 working hours per day, RIPP pays monthly on average an amount of 6527 Saudi Riyal (SR) as basic salary per worker. This means that RIPP pays on average 27.2 SR per regular working hour per worker. On the other side, the hourly overtime amount in Saudi Riyal is $150 \%$ of the hourly basic amount. RIPP considers any time over 40 working hours per week ( 8 hours per day, 5 working days per week) is an overtime per each worker. Meanwhile, there is a policy that a worker must not exceed 4 hours' overtime per day. RIPP, also, considers the physical year is 52 working weeks. Table 1 shows a summary of salary data of 15 mechanical maintenance employees in the year 2016.

From table 1, it can be observed the following main points:

- The total payment amount for the 15 mechanical workers in the maintenance department of RIPP is 1,359,659.34 SR in year 2016. This amount was based on basic payment amount equals to $848,510.00 \mathrm{SR}$ for 40 weekly working hours and 52 weeks in a year besides an overtime payment amount equals to 511,149.34 SR for 12,543.50 overtime hours recorded in year 2016.

- The overtime paid hours per year equals to $18,815.25$ hours $(12,543.50$ recorded overtime hours per year multiplied by 1.5 ). So, the overtime pay hours per week is 361.83 $(18,815.25$ divided by 52 weeks per year).

- By simple calculations, the average overtime per day is 34 hours $(12,543.50$ recorded overtime hours per year divided by 365 days a year). From the plant's policy that limit no worker exceeds 4 overtime hours per day, the number of workers required to cover the overtime demand including the weekends is 8 workers ( 34 overtime per day divided by 4 overtime daily allowable).

\section{Step 2: Workforce requirement analysis from one-month overtime record}

To ensure the above requirement, a sample data was taken from 30 days record of overtime. Then the average was calculated, and the result is that for every day the requirement is 8 labors including weekend as shown in Table 2.

\section{Step 3: Workforce requirement analysis from one-year work order record}

One-year record of work orders in 2016 has been retrieved from Computerized Maintenance Management System (CMMS) to calculate manpower required for normal 8 
working hours a day from Sunday to Thursday. The required manpower calculated as for each work order, there should be 2 workers according to safety policy. Table 3 shows part of the work orders data issued during the year 2016.

\section{Step 4: Statistical data of workforce requirement from one-year record of work orders}

By using Minitab software, the data in one-year record was processed to obtain the median of labor requirement for each day as given in Table 4. From Tables 1 and 2, the data is analyzed to know the number of workers that is required to cover the overtime demands which is 8 workers daily. Those 8 workers are added to the daily normal requirement that is generated from data given in Tables 3 and 4 .

Given the normal and overtime daily labors requirements from above analysis, the total daily manpower requirements can be expected as given in Table 6.

Table 5 shows the summary of workforce requirement resulted from the above analysis.

Table 1. Summary of 15 employees' salary data sheet (year 2016).

\begin{tabular}{|c|c|c|c|c|c|c|c|}
\hline $\begin{array}{c}\text { Employee } \\
\text { No. }\end{array}$ & $\begin{array}{c}\text { Employee } \\
\text { ID }\end{array}$ & $\begin{array}{c}\text { Monthly Basic } \\
\text { Salary (SR) } \\
\text { (1) }\end{array}$ & $\begin{array}{l}\text { Hourly Basic } \\
\text { Salary (SR) } \\
(2)=(1) / 30 / 8\end{array}$ & $\begin{array}{l}\text { Recorded Overtime } \\
\text { hours in the year } \\
2016 \text { (Hrs) } \\
\text { (3) }\end{array}$ & $\begin{array}{l}\text { Overtime payment } \\
\text { in year } 2016(\mathrm{SR}) \\
(4)=(2) \times 1.5 \times(3)\end{array}$ & $\begin{array}{l}\text { Basic Paymet in } \\
\text { year } 2016(\mathrm{SR}) \\
(5)=(2) \times 40 \times 52\end{array}$ & $\begin{array}{l}\text { Total Payment in } \\
\text { the year } 2016(S R) \\
(6)=(4)+(5)\end{array}$ \\
\hline Employee 1 & 50000007 & $6,593.00$ & 27.47 & 868.00 & $35,767.03$ & $57,139.33$ & $92,906.36$ \\
\hline Employee 2 & 50000008 & $9,436.00$ & 39.32 & 774.50 & $45,676.14$ & $81,778.67$ & $127,454.80$ \\
\hline Employee 3 & 50000019 & $6,309.00$ & 26.29 & 861.00 & $33,950.31$ & $54,678.00$ & $88,628.31$ \\
\hline Employee 4 & 50000085 & $6,156.00$ & 25.65 & $1,045.50$ & $40,225.61$ & $53,352.00$ & $93,577.61$ \\
\hline Employee 5 & 50000091 & $9,670.00$ & 40.29 & 822.00 & $49,679.63$ & $83,806.67$ & $133,486.29$ \\
\hline Employee 6 & 50000118 & $6,317.00$ & 26.32 & 655.00 & $25,860.22$ & $54,747.33$ & $80,607.55$ \\
\hline Employee 7 & 50000119 & $6,378.00$ & 26.58 & 902.00 & $35,955.98$ & $55,276.00$ & $91,231.98$ \\
\hline Employee 8 & 50000130 & $6,000.00$ & 25.00 & $1,262.00$ & $47,325.00$ & $52,000.00$ & $99,325.00$ \\
\hline Employee 9 & 50000134 & $6,705.00$ & 27.94 & 528.00 & $22,126.50$ & $58,110.00$ & $80,236.50$ \\
\hline Employee 10 & 50000135 & $5,678.00$ & 23.66 & 932.50 & $33,092.09$ & $49,209.33$ & $82,301.43$ \\
\hline Employee 11 & 50000166 & $3,689.00$ & 15.37 & 673.00 & $15,516.86$ & $31,971.33$ & $47,488.19$ \\
\hline Employee 12 & 50000172 & $4,749.00$ & 19.79 & 977.00 & $28,998.58$ & $41,158.00$ & $70,156.58$ \\
\hline Employee 13 & 50000177 & $5,650.00$ & 23.54 & $1,087.00$ & $38,384.69$ & $48,966.67$ & $87,351.35$ \\
\hline Employee 14 & 50000179 & $8,202.00$ & 34.18 & $1,097.50$ & $56,260.59$ & $71,084.00$ & $127,344.59$ \\
\hline Employee 15 & 50000196 & $6,373.00$ & 26.55 & 58.50 & $2,330.13$ & $55,232.67$ & $57,562.79$ \\
\hline \multicolumn{2}{|c|}{ Total } & $97,905.00$ & 407.94 & $12,543.50$ & $511,149.34$ & $848,510.00$ & $1,359,659.34$ \\
\hline
\end{tabular}

Table 2. Overtime record for one month.

\begin{tabular}{|c|c|c|c|c|c|c|c|c|c|c|c|c|c|c|c|c|c|c|c|c|c|c|c|c|c|c|c|c|c|c|c|}
\hline \multirow{2}{*}{ Employee } & \multicolumn{31}{|c|}{ Overtime Hours Per Day - 2016} \\
\hline & \begin{tabular}{|l|} 
FRI \\
\end{tabular} & SAT & SUN & MON & TUE & WED & THU & FRI & SAT & SUN & MON & TUE & WED $T$ & THU & FRI & SAT & SUN & MON & TUE & WED & THU & FRI & SAT & SUN $\mid N$ & MON & TUE & WED & THU & FRI & SAT & SUN \\
\hline Employee 1 & 0 & 0 & 0 & 0 & 0 & 0 & 0 & 0 & 0 & 0 & 0 & 0 & 0 & 0 & 0 & 0 & 0 & 0 & 3 & 3 & 3 & 8 & 8 & 3 & 3 & 3 & 3 & 3 & 8 & 8 & 3 \\
\hline Employee 2 & 0 & 0 & 0 & 0 & 3 & 3 & 0 & 8 & 0 & 3 & 2.5 & 2.5 & 3 & 0 & 0 & 12 & 2 & 0 & 0 & 3 & 3 & 8 & 8 & 3 & 3 & 3 & 3 & 3 & 8 & 8 & 3 \\
\hline Employee 3 & 8 & 8 & 0 & 0 & 3 & 3 & 3 & 8 & 0 & 0 & 3 & 0 & 3 & 3 & 0 & 8 & 3 & 0 & 3 & 3 & 3 & 8 & 8 & 3 & 3 & 3 & 3 & 3 & 8 & 8 & 3 \\
\hline Employee 4 & 8 & 8 & 0 & 3 & 3 & 3 & 0 & 0 & 8 & 3 & 3 & 3 & 3 & 3 & 8 & 0 & 3 & 3 & 3 & 3 & 3 & 8 & 8 & 3 & 3 & 3 & 3 & 3 & 8 & 8 & 3 \\
\hline Employee 5 & 0 & 0 & 0 & 0 & 0 & 0 & 0 & 0 & 0 & 0 & 0 & 0 & 0 & 0 & 8 & 0 & 0 & 0 & 0 & 3 & 3 & 8 & 8 & 3 & 3 & 3 & 3 & 3 & 8 & 8 & 3 \\
\hline Employee 6 & 0 & 8 & 0 & 0 & 2 & 3 & 3 & 8 & 8 & 3 & 3 & 3 & 0 & 0 & 0 & 8 & 2 & 0 & 3 & 3 & 3 & 8 & 8 & 3 & 3 & 3 & 3 & 3 & 8 & 8 & 3 \\
\hline Employee 7 & 0 & 0 & 3 & 3 & 3 & 0 & 2.5 & 0 & 0 & 3 & 3 & 2 & 0 & 2 & 8 & 0 & 2 & 0 & 3 & 3 & 3 & 8 & 8 & 3 & 3 & 3 & 3 & 3 & 8 & 8 & 3 \\
\hline Employee 8 & 8 & 8 & 3 & 5 & 3 & 3 & 3 & 8 & 8 & 3 & 3 & 3 & 3 & 3 & 8 & 8 & 3 & 3 & 3 & 4 & 6 & 8 & 8 & 6 & 5 & 4 & 4 & 4 & 8 & 8 & 6 \\
\hline Employee 9 & 0 & 8 & 0 & 0 & 0 & 0 & 3 & 0 & 0 & 3 & 3 & 3 & 3 & 0 & 0 & 0 & 0 & 0 & 1 & 3 & 3 & 8 & 8 & 3 & 3 & 3 & 3 & 3 & 8 & 8 & 3 \\
\hline Employee 10 & 0 & 8 & 4 & 0 & 0 & 0 & 3 & 0 & 0 & 3 & 3 & 3 & 3 & 0 & 8 & 0 & 2.5 & 2 & 1 & 3 & 3 & 8 & 8 & 3 & 3 & 3 & 3 & 3 & 8 & 8 & 3 \\
\hline Employee 11 & 0 & 0 & 0 & 0 & 0 & 0 & 0 & 0 & 0 & 0 & 0 & 0 & 0 & 0 & 0 & 0 & 0 & 0 & 0 & 3 & 3 & 8 & 8 & 3 & 3 & 3 & 3 & 3 & 8 & 8 & 3 \\
\hline Employee 12 & 0 & 8 & 0 & 0 & 3 & 3 & 0 & 0 & 0 & 0 & 0 & 3 & 0 & 0 & 0 & 0 & 0 & 0 & 0 & 3 & 3 & 8 & 8 & 3 & 3 & 3 & 3 & 3 & 8 & 8 & 3 \\
\hline Employee 13 & 0 & 0 & 0 & 0 & 0 & 0 & 3 & 0 & 8 & 0 & 0 & 0 & 3 & 3 & 0 & 8 & 0 & 0 & 0 & 3 & 3 & 8 & 8 & 3 & 3 & 3 & 3 & 3 & 8 & 8 & 3 \\
\hline Total hours per day & 24 & 56 & 10 & 11 & 20 & 18 & 20.5 & 32 & 32 & 21 & 23.5 & 22.5 & 21 & 14 & 40 & 44 & 17.5 & 8 & 20 & 40 & 42 & 104 & 104 & 42 & 41 & 40 & 40 & 40 & 104 & 104 & 42 \\
\hline \multirow[t]{2}{*}{ Head count per day } & 3 & 7 & 3 & 3 & 7 & 6 & 7 & 4 & 4 & 7 & 8 & 8 & 7 & 5 & 5 & 5 & 7 & 3 & 8 & 13 & 13 & 13 & 13 & 13 & 13 & 13 & 13 & 13 & 13 & 13 & 13 \\
\hline & & $\begin{array}{l}\text { Aver } \\
\text { work }\end{array}$ & $\begin{array}{l}\text { age of } \\
\text { king } 0\end{array}$ & $\begin{array}{l}\text { f work } \\
\text { T per }\end{array}$ & & & & Nork & & & & & & & & & & & & & & & & & & & & & & & \\
\hline
\end{tabular}


Table 3. Part of one-year records of work orders and manpower requirements for year 2016.

\begin{tabular}{|c|c|c|c|c|c|c|c|c|c|c|}
\hline \multicolumn{6}{|c|}{ \# of WORK ORDER ISSUANCE FOR 2016} & \multicolumn{5}{|c|}{$\begin{array}{l}\text { MANPOWER REQUIRED } \\
\text { FOR } 2016\end{array}$} \\
\hline & Sun & Mon & Tue & Wed & Thu & Sun & Mon & Tue & Wed & Thu \\
\hline DATE & 3-Jan-16 & 4-Jan-16 & 5-Jan-16 & 6-Jan-16 & 7-Jan-16 & & & & & \\
\hline $\mathrm{MECH}$ & 0 & 6 & 0 & 0 & 1 & 0 & 12 & 0 & 0 & 2 \\
\hline DATE & 10-Jan-16 & 11-Jan-16 & 12-Jan-16 & 13-Jan-16 & 14-Jan-16 & & & & & \\
\hline $\mathrm{MECH}$ & 1 & 2 & 2 & 4 & 2 & 2 & 4 & 4 & 8 & 4 \\
\hline DATE & 17-Jan-16 & 18-Jan-16 & 19-Jan-16 & 20-Jan-16 & 21-Jan-16 & & & & & \\
\hline $\mathrm{MECH}$ & 5 & 2 & 3 & 34 & 1 & 10 & 4 & 6 & 3 & 2 \\
\hline DATE & 24-Jan-16 & 25-Jan-16 & 26-Jan-16 & 27-Jan-16 & 28-Jan-16 & & & & & \\
\hline $\mathrm{MECH}$ & 0 & 5 & 1 & 1 & 1 & 0 & 10 & 2 & 2 & 2 \\
\hline DATE & 31-Jan-16 & 1-Feb-16 & 2-Feb-16 & 3-Feb-16 & 4-Feb-16 & & & & & \\
\hline $\mathrm{MECH}$ & 1 & 0 & 3 & 0 & 2 & 2 & 0 & 6 & 0 & 4 \\
\hline DATE & 7-Feb-16 & 8-Feb-16 & 9-Feb-16 & 10-Feb-16 & 11-Feb-16 & & & & & \\
\hline $\mathrm{MECH}$ & 0 & 1 & 1 & 0 & 0 & 0 & 2 & 2 & 0 & 0 \\
\hline
\end{tabular}

Table 4. Descriptive statistics for daily labor requirement of one-year record.

\begin{tabular}{|c|c|c|c|c|c|c|c|c|c|c|}
\hline Variable & $\mathrm{N}$ & $\mathrm{N}^{*}$ & Mean & SE Mean & StDev & Minimum & Q1 & Median & 23 & Maximum \\
\hline Sun & 45 & 7 & 7.956 & 0.911 & 6.112 & 0.000 & 2.000 & 8.000 & 12.000 & 30.000 \\
\hline Mon & 41 & 11 & 7.415 & 0.747 & 4.780 & 0.000 & 3.000 & 8.000 & 10.000 & 18.000 \\
\hline Tue & 47 & 5 & 6.043 & 0.532 & 3.647 & 2.000 & 4.000 & 6.000 & 8.000 & 22.000 \\
\hline Wed & 47 & 5 & 6.043 & 0.532 & 3.647 & 2.000 & 4.000 & 6.000 & 8.000 & 22.000 \\
\hline Thu & 42 & 10 & 6.429 & 0.694 & 4.495 & 2.000 & 2.000 & 6.000 & 10.000 & 18.000 \\
\hline
\end{tabular}

Table 5. Summary of workforce requirement identification.

\begin{tabular}{|c|c|c|c|c|c|c|c|}
\hline Work time patterns & Sun. & Mon. & Tue. & Wed. & Thu. & Fri. & Sat. \\
\hline $\begin{array}{c}\text { Single shift 8 hrs. a } \\
\text { day }\end{array}$ & 8 & 8 & 6 & 6 & 6 & 0 & 0 \\
\hline Overtime hrs. & $\mathbf{8}$ & $\mathbf{8}$ & $\mathbf{8}$ & $\mathbf{8}$ & $\mathbf{8}$ & $\mathbf{8}$ & 8 \\
\hline Total requirement & $\mathbf{1 6}$ & $\mathbf{1 6}$ & $\mathbf{1 4}$ & $\mathbf{1 4}$ & $\mathbf{1 4}$ & $\mathbf{8}$ & $\mathbf{8}$ \\
\hline
\end{tabular}

Table 6. Daily maintenance labor demand (r).

\begin{tabular}{|c|c|c|c|c|c|c|c|}
\hline Day $-\mathbf{i}$ & Sun. & Mon. & Tue. & Wed. & Thu. & Fri. & Sat. \\
\hline $\mathbf{r}_{\mathbf{i}}$ & 16 & 16 & 14 & 14 & 14 & 8 & 8 \\
\hline
\end{tabular}

\subsection{Phase II: The Proposed Model Formulation}

Based on the collected data, the optimum number of maintenance staff will be determined by proposing the following Integer Linear Programming (ILP) model for scheduling workers with two consecutive days off per week:
Minimize $W=\sum_{i=1}^{7} x_{j}$

Subject to

$\left(\sum_{i=1}^{7} x_{j}\right)-x_{i}-x_{i-1} \geq r_{i}$

$i=1, \ldots, 7$ 
$x_{j}, r_{i} \geq 0$ and integer,

$j=1, \ldots, 7$

Where

$W=$ Workforce size i.e. total number of workers assigned to all days off patterns.

$x_{j}=$ Number of workers assigned to days off pattern $j$ and $j+1$

$r_{i}=$ Minimum number of workers required on day $i$

There are two scenarios of work schedules are available to satisfy labor demand. The first scenario is to continue with current 5 days a week schedule from Sunday Thursday scheduling workers on weekend on overtime basis and calculating the labors hours per week as following;

$S_{1}=H \times T \times W_{c}$

Where:

$S_{1}=$ Labors hours per week for first scenario

$H=$ Standard 8 working hours per day

$T=$ Standard 5 working days per week

$W_{c}=$ Current workforce size

The second scenario is to switch from 5days to 7-days work week schedule with optimum workforce size and have two consecutive days off during weekdays for each worker. This will be done by using the proposed model's equations (1) and (2). The labor hours per week will be calculated with new optimum workforce size. Since the objectives are to find minimum workforce size and to reduce the overtime cost that is incurred due to non-availability of days-off schedule, the following equations are developed from workforce size model's equation (1):

$S_{2}=\left(\sum_{i=1}^{7} x_{j}\right)(H)(T)$

Given that $W=\sum_{i=1}^{7} x_{j}$
So, $S_{2}=W \times H \times T$

Where:

$S_{2}=$ Labors hours per week for second scenario

$H=$ Standard 8 working hours per day

$T=$ Standard 5 working days per week

$W=$ Workforce size i.e. total number of workers assigned to all days off patterns.

The labors hours per week for both scenarios will be compared to show the labors hours saving resulting from days off scheduling.

$H_{\text {saving }}=S_{1}-S_{2}$

Where:

$H_{\text {saving }}=$ hours saving per week resulted from proposed ILP model.

\section{Validation of the Proposed Methofdology}

Two solution scenarios will be compared to show the recommended solution with cost saving. The first scenario is the existing five days applied by RIPP and the second one is based on the proposed ILP model that switched from five to seven days-off schedules.

\subsection{Scenario 1: Continue with Current 5- Day Schedule}

In this scenario, maximum of 15 mechanical maintenance workers assigned on regular-time basis which is 5-day schedule for one morning shift ( 8 hours) from Sunday to Thursday. Any hours outside these 8 hours including the working hours in the weekends are considered as over-time basis. Table 7 portrays the details of the regular pay hours' calculations based on equation (4).

As mentioned, and observed from the information given in Table 1, the ovestime pay hours per week is 361.83 . So, the total pay 
hours per week $\left(S_{1}\right)$ for the 5-day schedule scenario is:

$\mathrm{S}_{1}=$ regular pay hours + overtime pay hours = $600+361.83=961.83$ hours per week.

\subsection{Scenario 2: Switch to 7-Day Work Week}

In this scenario, the 5-day workweek is extended to 7-day workweek. The proposed ILP model will be used to optimize the size of mechanical maintenance workforce and to define the working days' schedule that satisfy the daily maintenance requirements. The proposed model is based on the $(5,7)$ days-off approach. In this model, each worker is assigned one work stretch of 5 consecutives workdays at any given cycle. Within the same work cycle, a worker is given a break of 2 consecutive days off after the completion of his workweek stretch. Therefore, instead of the weekends off during the weeks' cycle, each worker gets 2-day break at any days in the week. The procedure for deriving the minimum workforce size and allocating workers to the days-off patterns are produced. This days-off schedule works under the assumptions that the workers required on weekdays are more than those expected during the weekend and that each worker must have 2-day off within the given cycle.

Given the requirements in Table 6, the proposed model was applied using Microsoft Office 365 Excel Solver. The optimum size of mechanical maintenance workforce and the number of workers assigned to days-off pattern resulted from the proposed model are given in Tables 8 and 9 respectively. Table 8 shows that it is required 18 workers to satisfy the daily requirements given in Table 9. Since each worker is given two consecutive days off per week, each worker is paid for 5 work days per week at eight hours per day. Based on that, Table 10 portrays the details of the regular pay hours' calculations based on equation (6).

As observed from Table 10, there is no overtime pay hours per week is required as the daily assigned workers equals exactly the daily required workers. So, the total pay hours per week $\left(\mathrm{S}_{2}\right)$ for the 7-day schedule scenario can be calculated as follows:

$\mathrm{S}_{2}=$ regular pay hours + overtime pay hours $=$ $720+0=720$ hours per week.

Table 7. Pay hours per normal 5 working days (Scenario \#1).

\begin{tabular}{|c|c|c|c|c|c|}
\hline Working Days & $\begin{array}{c}\text { Number of } \\
\text { Workers } \\
\text { (Wc) }\end{array}$ & $\begin{array}{c}\text { Regular Hours per } \\
\text { Shift (Hrs) } \\
(\mathbf{H})\end{array}$ & $\begin{array}{c}\text { Regular Hours per } \\
\text { Week (Hrs) } \\
(\mathbf{T})=(\mathbf{W c}) \mathbf{x}(\mathbf{H})\end{array}$ & $\begin{array}{c}\text { Reular Pay Rate (\%) } \\
\text { (R) }\end{array}$ & $\begin{array}{c}\text { Regular Pay Hours } \\
\text { Per Week (Hrs) } \\
\left(\mathbf{S}_{1}\right)\end{array}$ \\
\hline Sunday - Thursday & 15 & 8-hour x 5-day $=40$ & 600 & $100 \%$ & 600 \\
\hline
\end{tabular}

Table 8. Optimal days-off assignments for mechanical maintenance workers (Scenario \#2).

\begin{tabular}{|c|c|c|c|c|c|c|c|c|}
\hline Days-Off Pattern (i) & $\mathbf{1}$ & $\mathbf{2}$ & $\mathbf{3}$ & $\mathbf{4}$ & $\mathbf{5}$ & $\mathbf{6}$ & $\mathbf{7}$ & Total \\
\hline $\begin{array}{c}\text { Number of Workers } \\
\text { (X) Assigned to Day- } \\
\text { Off Pattern (i) }\end{array}$ & 2 & 0 & 2 & 2 & 2 & 2 & 8 & 18 \\
\hline
\end{tabular}


Table 9. Optimal daily mechanical maintenance workers' assignment Scenario \#2.

\begin{tabular}{|c|c|c|c|c|c|c|c|c|c|}
\hline \multirow{2}{*}{ Week Days } & \multicolumn{7}{|c|}{ Number of Workers Assigned to Days-Off Pattern } & \multirow{2}{*}{$\begin{array}{l}\text { Total Daily } \\
\text { (Assigned) }\end{array}$} & \multirow{2}{*}{$\begin{array}{l}\text { Total Daily } \\
\text { (Required) }\end{array}$} \\
\hline & $\mathrm{X} 1$ & $\mathrm{X2}$ & X3 & $\mathrm{X4}$ & $\mathrm{X5}$ & $\mathrm{X6}$ & $\mathbf{X 7}$ & & \\
\hline Sunday & Off & Off & 2 & 2 & 2 & 2 & 8 & 16 & 16 \\
\hline Monday & 2 & Off & Off & 2 & 2 & 2 & 8 & 16 & 16 \\
\hline Tuesday & 2 & 0 & Off & Off & 2 & 2 & 8 & 14 & 14 \\
\hline Tuesday & 2 & 0 & 2 & Off & Off & 2 & 8 & 14 & 14 \\
\hline Wednesday & 2 & 0 & 2 & 2 & Off & Off & 8 & 14 & 14 \\
\hline Thursday & 2 & 0 & 2 & 2 & 2 & Off & Off & 8 & 8 \\
\hline Friday & Off & 0 & 2 & 2 & 2 & 2 & Off & 8 & 8 \\
\hline
\end{tabular}

Table 10. Pay hours based on $(5,7)$ days-off approach proposed by Scenario \#2.

\begin{tabular}{|c|c|c|c|c|c|}
\hline $\mathbf{( 5 , 7 )}$ Days-Off & $\begin{array}{c}\text { Number of } \\
\text { Workers } \\
\text { (W) }\end{array}$ & $\begin{array}{c}\text { Regular Hours per } \\
\text { Shift (Hrs) } \\
\mathbf{( H )}\end{array}$ & $\begin{array}{c}\text { Regular Hours per } \\
\text { Week (Hrs) } \\
\text { (T) }=\mathbf{( W )} \mathbf{~ ( H )}\end{array}$ & $\begin{array}{c}\text { Reular Pay Rate (\%) } \\
\text { (R) }\end{array}$ & $\begin{array}{c}\text { Regular Pay Hours } \\
\text { Per Week (Hrs) } \\
\left(\mathbf{S}_{2}\right)\end{array}$ \\
\hline Sunday - Saturday & 18 & 8-hour $\times$ 5-day $=40$ & 720 & $100 \%$ & 720 \\
\hline
\end{tabular}

\subsection{Comparison Between the Two Alternative 5-Day and 7-Day Scenarios}

To determine the features of applying the proposed 7-day scenario, the following calculations can be constructed from the results obtained from this scenario compared with those that can be obtained from the current 5-day scenario (the results of these calculations are summarized in Table 11):

Table 11. Comparative results between the current 5day and the proposed 7-day scenarios.

\begin{tabular}{|c|c|c|}
\hline Scheduling Scenario & Workforce Size & $\begin{array}{c}\text { Pay Hours } \\
\text { Cost/year }\end{array}$ \\
\hline $\begin{array}{c}\text { Scenario \#1: } \\
\text { 5-day (Current RIPP } \\
\text { Model) }\end{array}$ & 15 & $1,360,412 \mathrm{SR}$ \\
\hline $\begin{array}{c}\text { Scenario \#2: } \\
\text { 7-day (Proposed Days- } \\
\text { Off Model) }\end{array}$ & 18 & $1,018,368 \mathrm{SR}$ \\
\hline \multicolumn{2}{|c|}{ Saving cost amount per year } & $342,044 \mathrm{SR}$ \\
\hline \multicolumn{2}{|c|}{ Pay hours cost saving (\%) } & $25 \%$ \\
\hline \multicolumn{2}{|c|}{ Overtime cost saving (\%) } & $67 \%$ \\
\hline
\end{tabular}

- The total paid hours per week from 7day scenario is 720 hours compared with 961.831 hours from 5-day scenario with saving 241.831 hours weekly. Since RIPP is considering the physical year consists of 52 weeks, the yearly paid hours from 7-day scenario will be 37,440 hours compared with 50,015.21 hours from 5-day scenario. This means 7-day scenario is saving about $25 \%$ of the paid hours than 5-day scenario.

- Based on the information given in Table 7 for 5 -day scenario, the regular pay hours per week is 600 hours with 27.2 SR regular pay per hour and the overtime pay hours per week is 361.831 hours with 40.8 SR $(27.2 \times 150 \%)$ overtime pay per hour. This means 5-day scenario will cost weekly 26,161.78 SR (i.e., cost yearly 1,360,412 SR = 26161.78 x 52 weeks per year).

- Based on the information given in Table 10 for 7-day scenario, there is only regular pay hours per week which is 720 hours with 27.2 SR regular pay per hour. This means 7-day scenario will cost weekly 19,584 SR (i.e., cost yearly $1,018,368 \mathrm{SR}=19,584 \mathrm{x}$ 52 weeks per year).

- The above two points showed that there is a saving in the yearly cost equal to 342,044 SR using 7-day scenario instead of 5day scenario. On the other side, Table 1 showed that the cost of the total overtime for the year 2016 equals to 511,149 SR. 
Considering the amount of $342,044 \mathrm{SR}$ is deducted from the amount of 511,149 SR, there is a saving equal to $67 \%$.

\subsection{The Proposed Model Validation for Implementation}

For a real implementation of the proposed model (scenario 2), it must not violate RIPP working policies at the maintenance department. The following points proves that the proposed 7-day scheduling model satisfies all these policies:

- There is always one worker on vacation, training or sick leave so, RIPP is assumed that only 14 workers are available out of the current 15 throughout the year. This assumption is satisfied since the maximum requirement of workforce per day after implementation of the proposed scheduling model (Scenario 2) is 16 workers.

- Labor office regulations require plants to have 8 hour working days for five days a week. This assumption is also satisfied since each employee works 8 hours per day and 2 days off per week as shown in Table 9.

- Critical system failure must be repaired immediately. This assumption is satisfied as well since days off scheduling allow employees to be available all week days.

- The workforce is available any time and can operate for any workplace. This assumption is satisfied as well since days off scheduling allow employees to be available all week days and operate for any work place related to mechanical maintenance.

- Each employee should have two consecutive days off per week. This constraint is also satisfied since each employee is scheduled to have 2 consecutive days off as illustrated in Table 9.
By the above results, it is proved that the proposed 7-day scheduling scenario is valid for implementation at RIPP with $25 \%$ saving in the total pay hours per year and $67 \%$ saving in the cost of overtime per year for the mechanical maintenance workers.

\section{Conclusions and Recommendations}

The primary objective of this paper is to solve the problem facing the maintenance department at Rabigh Independent Power Plant (RIPP). It is required to specify optimum mechanical maintenance workforce schedules to limit the increasing demand for overtime during the five working days of the week and the two days of a weekend. Another objective is to reduce the cost of maintenance workers' overtime by utilizing the available work time within minimum requirements. To achieve these two objectives, an integer linear programming model is proposed. The model is based on $(5,7)$ days-off approach and defined as 7-day scenario. By applying this scenario using real data collected for year 2016, the following conclusions are obtained compared with the current 5-day scenario:

- The suggested workforce size is 18 workers compared with the current size which is 15 workers. Despite the workforce size is increased by $20 \%$, the pay hours cost per year is reduced by $25 \%$ and the overtime cost is reduced by $67 \%$.

- The proposed 7-day scenario fulfilled all the maintenance working policies by the plant such as:

- One worker can be out of the work without affecting the maintenance demands,

- Each worker has 8 hours working days for five days a week and two consecutive days off, and 
○ The workers are available all week days and operate for any work place related to mechanical maintenance.

In addition, the following points are recommended for future studies:

- The maintenance management at RIPP study the validity of the 7-day scenario to remaining sections of maintenance department to increase the saving and enhance company's profit.

- The management must focus on daily employees' productivity. The degradation of employees' productivity could lead to excessive overtime demand. Seven-day schedule with productivity control measures will lead to more saving in workers' assignment hours.

- Human factors are significant to the performance of any profitable plant. Some of the employees would have some degree of reservation towards the new seven-day schedule as they would force themselves to work all weekends without overtime pay. Therefore, it is recommended from management to pay careful attention to employee morale when this schedule is implemented.

\section{References}

[1] International Energy Agency (2016) "World Energy Investment". Retrieved February 02, 2019, from https://www.iea.org/newsroom/news/2016/september/w orld-energy-investment-2016.html.

[2] Ventures Onside for Middle East Electricity (2016) "GCC Power Market Overview 2016", Retrieved
February 02, 2019, from: http://www.transformersmagazine.com/images/News/PDF/GCC-Power-Market2016.pdf.

[3] Electricity Cogeneration Regulatory Authority (2017) "Bringing Demand-Side Management to The Kingdom of Saudia Arabia", Retrieved June 14, 2017, from; www.ecra.gov.sa/enus/ECRAStudies/Documents/Bringi ng\%20Demand.pdf.

[4] Bergh, J. Van den, Beliën, J., Bruecker, Philippe, De Demeulemeester, E. and De Boeck, L. (2013) "Personal Scheduling: Literature Review", European Journal of Operational Research, 226(1): 367-385.

[5] Urmila, S. P. and Dinesh, B.H. (2013) "Literature Review on Personal Scheduling", International Journal of Computer Engineering and Technology, 4(5): 312324.

[6] Alfares, H. K., Lilly, M. T. and Emovon, I. (2007) "Maintenance Staff Scheduling at Afam Power Station", Industrial Engineering and Management Systems, 6(1): 22-27.

[7] Ikuobase, E., Macaulay, T. L., Stephen, O. and Tamuno-Ojuemi, O. (2012) "Design of Software for Maintenance Workforce Scheduling (A Case Study of Afam Power Station, Nigeria)", Engineering, 4(5): 235244.

[8] Jonas, V., Andreas, F. and Jens, O. B. (2017) “A column generation approach for the integrated shift and task scheduling problem of logistics assistants in hospitals", European Journal of Operational Research, 260(1): 316-334.

[9] Bagheri, M., Devin, A. and Izanloo, A. (2016) “An application of stochastic programming method for nurse scheduling problem in real world hospital", computers and industrial engineering, 96(1): 192-200.

[10] Al-Shayea, Adel M. (2012) "Maintenance Capacity Planning: Determination of Maintenance Workforce", Engineering, 4(1): 37-43.

[11] Elshafei, M. and Alfares, H. K. (2008) "A dynamic programming algorithm for days off scheduling with sequence dependent labor costs", Journal of Scheduling, 11(12): 85-93. 


\section{نموذج رياضي مقترح لتحسين جدولة القوى العاملة في قسم الصيانة بمحطة كهرباء رابغ المستقلة}

\section{علي محرق جعفري، و رضا محمد سعيد عبد العال}

قسم الهندسة الصناعية، كلية الهندسة، جامعة الملك عبد العزبز، جدة، المدلكة العربية السعودية

amj.655@gmail.com

المستخلص. تعتبر الصيانة في الصناعات المنتجة للطاقة جزءًا مهمًا للحفاظ على توافر وموثوقية نظام المحطة على المستوى الأمثل، حيث إن الاستخدام الأمثل لموارد الصيانة - مثل

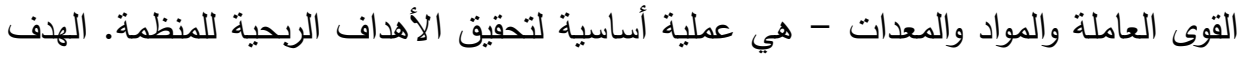
الأساسي لهذه الدراسة البحثية هو حل المشكلة التي تواجه إدارة الصيانة في محطة رابغ المستقلة لإنتاج الكهرباء، والتي تتطلب تحديد الجداول المثلى للقوى العاملة في مجال الصيانة الميكانيكية للحد من الطلب المنزايد على العمل الإضافي خلال أيام العمل الخمسة من الأسبوع ويومي لُّي عطلة نهاية الأسبوع. هنالك هدف آخر، هو خفض تكلفة ساعات العمل الإضافية للعاملين في مجال الصيانة من خلال الاستفادة من وقت العمل المتاح في الحد الأدنى من المتطلبات. ولتحقيق هذين الهدفين، تم اقتراح نموذج برمجة خطية مناسب لحل المشكلة. يعتمد النموذج من على نهج الجدولة (OV) والمعرف بسيناريو السبعة أيام، ومن خلال نطبيق هذا السيناريو

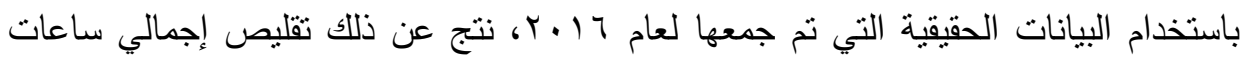

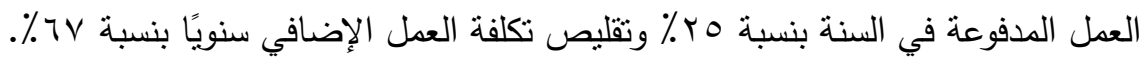

كلمات مفتاحية: جدولة القوى العاملة، تحليل التكاليف، موثوقية محطة الطاقة، البرمجة الخطية،

$$
\text { سياسات العمل في الصيانة. }
$$

